\title{
Bibliographic Control for History of Science Commission on Bibliography and Documentation of the IUHPST/DHST
}

\author{
Birutè Railienè \\ The Wroblewski Library of the \\ Lithuanian Academy of Sciences \\ Žygimantų g. 1, \\ Vilnius LT-01102, Lithuania \\ E-mail: railiene@mab.lt
}

\section{Early development of the commission}

Bibliographic control has been accepted for centuries among librarians, though nowadays it is spreading rather rapidly to other fields of knowledge. The new technologies offer us not only open access to information, but also the possibility of becoming drowned in it. Over the years, document-archiving strategy, along with development of bibliography, have been widely discussed within the International Union of History and Philosophy of Science and Technology / Division of History of Science and Technology (IUHPST/DHST). In 1993, two separate DHST commissions (Bibliography and Documentation) joined to create a Commission for Bibliography and Documentation (CBD). The first professional event sponsored by the CBD was a workshop on bibliography and documentation in 1995 in Liége. From that time on, the CBD adopted the goal of making bibliographic data more widely available in electronic form (Home, 1996, p. 309).

The international community of bibliographers and archivists discussed the need to cooperate on archives of science in Europe and they agreed to create a working group at the European level on contemporary scientific archives. The acronym CASE was adopted, and the project was officially launched during the $22^{\text {nd }}$ conference of DHST in 1997 in Liége. The CBD became a technical assistant of the CASE, offereing to host a CASE website in association with the UK National Cataloguing Unit for the Archives of Contemporary Scientists (NCUACS) at the University of Bath. CASE remained an informal grouping of colleagues, 
often meeting on the back of other international meetings (Harper, 1999, p. 1). The NCUACS closed in 2009 and their work is being continued by the Centre for Scientific Archives at the Science Museum in London (NCUACS, n.d., p. 1).

Currently the Commission on Bibliography and Documentation aims to foster the development and utilization of bibliographic and archival documentation within the IUHPS/DHST and to assist historians in their study of science and technology. The commission supports dissemination of knowledge about the archives and bibliography of the history of science and technology to the wider community.

The commission identifies and pursues projects that support its purpose, including prizes and awards; it seeks funds from a range of agencies and funding bodies to support its projects as opportunities arise.

\section{World History of Science Online}

During a CBD meeting in 2000 in Brussels, the CBD appointed a committee to draft a resolution for preserving the historically valuable papers and electronic records of modern science and making them accessible to researchers. The Brussels resolution provided a basic framework for preserving the records of scientific organizations and the papers of leading scientists internationally. The resolution was approved by the General Assembly of the Division of History of Science of the IUHPS at the XXI International Congress of History of Science at its meeting in Mexico City (2001), was forwarded to the International Council of Scientific Unions (ICSU) for action, and appeared in a Vademecum of the IUHPS/DHST. The complete text of the resolution was published in the American Institute of Physics History Newsletter (IUHPS, 2001, p. 1).

The CBD in cooperation with the Conseil International de la Philosophie et des Sciences Humaines (CIPSH) arranged a working meeting for the Online Dictionary of National History of Sciences Bibliographies and Archival Sources (Paris, 2002). This initiative, with the strong input of the international advisory board, became one of the most prominent projects of the CBD—World History of Science Online (Paris, 2003). The fundamental goal of the project is the idea to propose a free resource for scholars worldwide about databases of bibliographic and archival sources in the field of history of science and technology (CBD, 2012, p. 1). A more extended information about WHSO project will follow (see Weldon, 2013). 
Neu-Whitrow prize

Following its initial agenda of making bibliographic data more widely available in electronic form, the CBD investigated new forms of visibility for bibliographic activities. Since 2013 happened to coincide with the centenary of the Isis Bibliography of the History of Science, founded by George Sarton (1884-1956), the CBD decided to establish a prize for the best bibliography or manuscriptfinding aid. It was approved and supported by the DHST. The prize, named after two outstanding bibliographers and historians of science, John Neu (b. 1935) and Magda Whitrow (1914-2011), is awarded every four years, during the international congress of the DHST. In 2013, the winner of the Neu-Whitrow Bibliography Prize was Jennifer Rampling, who presented the Catalogue of the Ripley Corpus (Neu-Whitrow..., 2013, p. 1).

\section{Endorsed projects}

With an international constituency, the members of the CBD and Advisory Board follow the latest professional issues in bibliography and archival matters, and they participate in relevant international activities. Even without any substantial financial support, the CBD advocates for important projects and initiatives. The endorsed projects include CESIMA, a Brazilian institute working on classification in the history of science; CSA, a project for management and description of private scientific archives; ETD, a project for database of digital $\mathrm{PhD}$ abstracts; and Isis Current Bibliography, which is developing a new digital platform for document indexing.

\section{Sharing experience}

The CBD and Advisory Board members are widely dispersed around the globe. The commission meets every four years at the international congresses of the IUHPST/DHST. Periodically, other meetings are organized at international scientific events of history of science associations in the world. During the last few years, the $\mathrm{CDB}$ extended the sharing of professional experience and organized several symposia during these events: 
- "History of Science and the New Media: Resources for Connecting the Global Community of Scholars" (Budapest, 23 ${ }^{\text {rd }}$ ICHST, 2009);

- "Classification in the History of Science" (Phoenix, Arizona, USA, HSS Annual Conference, 2009);

- "The Tools of Research and the Craft of History" (Athens, $5^{\text {th }}$ Congress of the ESHS, 2012);

- "New Perspectives on Classification" and "History of Science and Ecology of Knowledge" (Manchester, 24 $4^{\text {th }}$ ICHSTM, 2013).

\section{Presidents of the CBD:}

- 1993-1997 Roderick W. Home (University of Melbourne, Australia)

- 1997-2000 Roderick W. Home (University of Melbourne, Australia)

- 2001-2005 Peter Harper (National Cataloguing Unit for the Archives of Contemporary Science, University of Bath, UK)

- 2005-2009 Peter Harper (National Cataloguing Unit for the Archives of Contemporary Science, University of Bath, UK)

- 2009-2011 Roberto de Andrade Martins (Group of History and Theory of Science, Universidade Estadual de Campinas (Unicamp), Brazil).

- 2011- Birute Railienè (Wroblewski Library of the Lithuanian Academy of Sciences, Lithuania)

\section{Advisory Board}

During the quadrennial congressional meeting in Manchester, UK (2013) the Commission's Executive Board created a board of advisors. The current advisory board is below:

- $\quad$ Barett, Anne (UK)

- Bromberg, Carla (Brazil)

- Chaplin, Simon (UK)

- Ferraz, Marcia (Brazil)

- Gerali, Francesco (Italy)

- Home, Rod (Australia) 


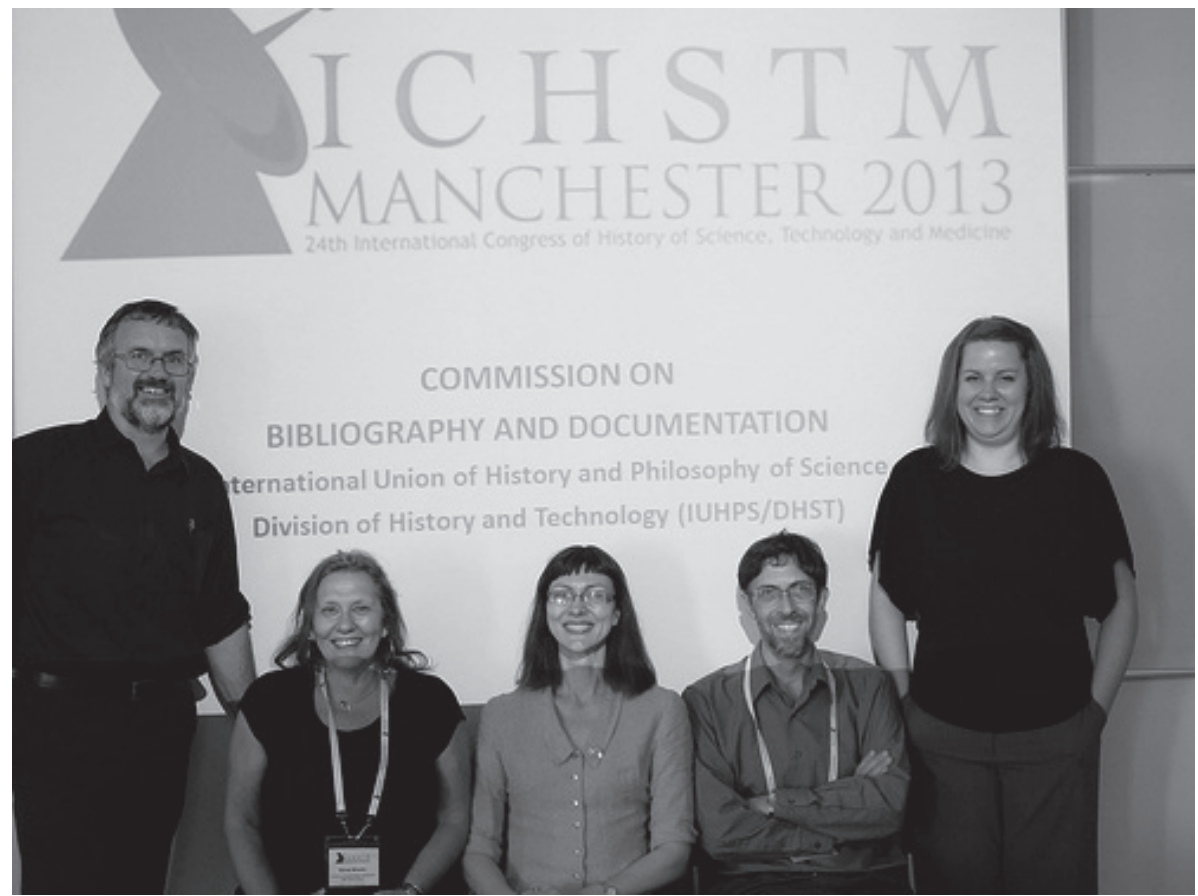

Board of the Commission on Bibliography and Documentation during the iCHSTM (Manchester, 2013). From the left: Gavan McCarthy (Vice President for Archives), Silvia Waisse (Secretary), Birutė Railienè (President), Stephen Weldon (Vice President for Bibliography), and Amy Rodgers (Treasurer). Photo by Helen Morgan.

- James, Frank (UK)

- Malone, Jay (USA)

- Pisano, Raffaele (Italy)

- Rabl, Irene (Austria)

- Rampling, Jennifer (UK)

- Stewart, John (USA)

- Tarcitano Conrado M. Filho (Brazil)

The $\mathrm{CBD}$ has been receiving international attention via the projects and information dissemination initiatives; it is documented in the WHSO database. The visibility of the CBD has improved since the new website was created by the eScholarship Research Centre (University of Melbourne) and launched in 2012 at https://sites.google.com/site/cbibdoc/home. 


\section{References}

CBD (2012), Commission on Bibliography and Documentation, Division of History of Science and Technology, IUHPS [homepage]. Retrieved from https://sites.google. $\mathrm{com} /$ site/cbibdoc/home/board-2001-2005 [accessed 31 Aug 2013]

Harper, P. (1999), "Work of the 'Cooperation on the Archives of Science in Europe' (CASE) Group,” AIP History Newsletter, vol. 31, no. 2. Retrieved from http://www. aip.org/history/newsletter/fall99/case.htm [accessed 31 Aug 2013]

Home, R. W. (1996), 'Towards an International Bibliographical Database in the History of Science, Technology and Medicine,' Nuncius: Annali di Storia della Scienza, vol. 11, pp. 309-314.

IUHPS (2001), 'The International Union of History and Philosophy of Science Approves Resolutions on Preserving the Records of Modern Science,' AIP History Newsletter, vol. 33, no. 2. Retrieved from http://www.aip.org/history/newsletter/fall2001/ iuhps.htm [accessed 31 Aug 2013]

NCUACS (n.d.), National Cataloguing Unit for the Archives of Contemporary Scientists (NCUACS), Archives Hub Contributors. Retrieved from http://archiveshub.ac.uk/ contributors/ncuacs.html [accessed 31 Aug 2013]

Neu-Whitrow... (2013), 'Neu-Whitrow Bibliography Prize,' IUHPS-DHST Commission on Bibliography and Documentation. Retrieved from https://sites.google.com/site/ cbibdoc/projects-and-prizes/neu-whithrow-prize [accessed 31 Aug 2013]

Weldon, S. P. (2013), 'The World History of Science Online: A Project of the Commission on Bibliography and Documentation,' Acta Baltica Historiae et Philosophiae Scientiarum, vol. 1, no. 2, pp. 97-101.

http://dx.doi.org/10.11590/abhps.2013.2.09 